\title{
St. Louise Hospital for Marginalized Homeless Population: TB and Other Infectious Diseases are Rare
}

P. Tomanek (Pavol Tomanek)', M. Hardy (Maria Hardy)', K. Prochazkova (Katerina Prochazkova)',2, G. Mikolasova (Gertruda Mikolasova)2, V. Krcmery (Vladimir Krcmery) 1,3, M. Mikloskova (Monika Mikloskova)', L. Bucko (Ladislav Bucko)', , M. Mrazova (Mariana Mrazova)', M. Karvaj (Marian Karvaj)', M. Jankechova (Monika Jankechova)', J. Vallova (Jana Vallova)', V. Hulkova (Viera Hulkova)', I. Bartosovic (Ivan Bartosovic)', P. Slovak (Peter Slovak)', R. Vlcek (Robert Vlcek)', J. Benca (Juraj Benca)', A. Skopova (Ana Skopova)', I. Jahodova (Ivana Jahodova)', M. Nachtmann (Michaela Nachtmann) ${ }^{5}$ and A. Shahum (Andrea Ahahum)', J. Bozik (Jozef Bozik) ${ }^{6}$

Original Article

${ }^{1}$ St. Louise de Marillac Hospital for homeless, Join project of St. Elisabeth University and CM De Paul, KE

2 The Vincentine Order (Congregatio Missiorum CM in St. Lazarous), IT

${ }^{3}$ Institute of Microbiology, Medical School of Commenius University Bratislava, SK

${ }^{4}$ Med. Univ. of North Carolina at Chapel Hill, NC, USA

5 St. Elizabeth University PhD. and MSc. Program, Bratislava, SK and St. John Paul School, and St. Lesley College, N. Zámky, SK

${ }^{6}$ St. Elizabeth University, Bratislava, SK

\section{E-mail address:}

tropicteam@gmail.com

\section{Reprint address:}

Pavol Tomanek,

St. Louise de Marillac Hospital

SEU program for homeless

Suource: Clinical Social Work and Health Intervention

Pages: $46-49$
Volume: 8

Cited references: 10
Issue: 1

\section{Reviewers:}

Dr. Daria Kimuli, Ph.D.

Catholic university of Eastern Africa

Nairobi, KE

Katrina Mulama, MD

General Hospital, SM, Nairasha

Rongai, KE 


\section{Key words:}

Marginalized homeless population.

\section{Publisher:}

International Society of Applied Preventive Medicine i-gap

CSWHI 2017; 8(1): 46 - 49; DOI 10.22359/cswhi_8_1_10 @ 2017 Clinical Social Work and Health Intervention

\section{Abstract:}

The aim of this retrospective study was to provide an overview of reasons for hospitalization in a homeless devoted hospital of St. Louise de Marillac with 25 beds serving an urban homeless population. The majority of 25 beds are filled by patients with civilization and psychosocial diseases related to permanent stress and marginalization such as hypertension, diabetes, motion pathology after trauma and chronic alcohol intoxication. Communicable diseases such as severe RTI, scabies, skin/ soft tissue infections and leg ulcers were the only ID observed. However, no case of Hepatitis A, HBV, HIV, TB or infections diarrhea have been observed within the last year.

\section{Conflict of interest:}

The authors whose names are listed in the title of the article certify that they have NO affiliations with or involvement in any organization or entity with any financial interest (such as honoraria; educational grants; participation in speakers' bureaus; membership, employment, consultancies, or other equity interest), or non-financial interest (such as personal or professional relationships, affiliations, knowledge or beliefs) in the subject matter or materials discussed in this manuscript.

\section{Introduction}

Homelessness in Central Europe V4 countries with former socialist social security system is a common phenomenon. Also the homeless population in the whole EU is increasing.(1-2) The homeless population is in substantial risk of medical, psychiatric, and social problems such as tuberculosis, HIV infection, hepatitis, alcoholism and substance abuse, skin and foot disease, schizophrenia and related psychoses, malnutrition, and trauma. About 5-10,000 homeless are registered within 10 major Slovak urban cities with population of about 1.2 mil citizens. (3-5) The aim of this short communication is to describe the spectrum of diagnoses for hospitalization within a 25 bed hospital for the homeless in St. Louise de Marillac in 2016.

\section{Patients and Methods}

St. Louise de Marillac Hospital was funded solely for homeless people to cover their health care needs due to the experience of systematical exclusion of the homeless population from chronic health care. The majority of these patients are therefore forced to misuse emergency departments for their problems which causes delay of care for urgent patients and significant costs. Some charities, such as St. Elizabeth University and St. Vincent de Paul Order (Lazarists) 
of the Slovak Province are providing shelters and social care for patients. Hospital for homeless had about 256 patients hospitalized for 1-182 days in 2016. One nurse is present during the day and a doctor plus pharmacist is visiting twice weekly.

\section{Results and Discussion}

The commonest diagnoses for in-patients in the St. Louise de Marillac Hospital were infectious, but were related to homelessness in correlation with our expectations (skin and soft tissue diseases, parasites, leg ulcers, freezing - less necrosis related in winter, RTI, etc.). Other major groups of diseases were psychosocial disorders and stress-related diseases such as depression, hypertension, diabetes, asthma which were present in $80-85 \%$ of all admissions apart of February (influenza month), where upper respiratory system infections (RTI) were prevalent as similarly described from shelters worldwide (6-8) or from refugee camps (4).

\section{Conclusions}

The majority of beds in hospitals for homeless patients are covered by patients with civilization and psychosocial diseases related to the permanent stress and marginalization such as hypertension, diabetes, motion pathology after trauma and chronic alcohol intoxication. Infectious diseases such as severe RTI or scabies or skin/soft tissue infected ulcers were the only IDs which were observed. No case of Hepatitis A, HBV, HIV, TB or infectious diarrhea have been observed within the last year.

\section{References}

1. FAZEL S, GEDDES JR, KUSHEL M (2014) The health of homeless people in high-income countries: descriptive epidemiology, health consequences, and clinical and policy recommendations. The Lancet, 384(9953), 15291540. doi:10.1016/s0140-6736(14)61132-6
2. MCCORMICK B, WHITE J (2016). Hospital care and costs for homeless people. Clinical Medicine, 16(6),

3. MIKULAKOVA, W., KLIMOVA, E., KENDROVA, L. 2015: Utilization of rehabilitation in patients with fatigue Influenced sclerozou multiplex In: Rehabilitácia ISSN 0375-0922, Vol. 52, 2015, No 3, p. 149-159

4. KOVÁČ, R., MIKLOŠKOVÁ, M. (2013). The Impact of Early Childhood on the Risk of the Homelessness, p.80-89. In: The International Journal of Prenatal and Perinatal Psychology and Medicine, Volume 25, Supplement 1, 2013, Society of Integrated sciences. ISBN 0943-5417, 506-510. doi:10.7861/clinmedicine.16-6-506

5. ARNAUD A, CHOSIDOW O, DETREZ M, BITAR D, HUBER F, FOULET F, VANDENTORREN S (2015) Prevalences of scabies and pediculosis corporis among homeless people in the Paris region: results from two randomized cross-sectional surveys (HYTPEAC study). British Journal of Dermatology, 174(1), 104-112. doi:10.1111/ bjd. 14226

6. DUDOVA Z., TRILISINSKAYA Y., JACKULIAKOVA T., JANKECHOVA M., SASVARY F., MATEL A., HAJJ ALI I. (2016). Six month follow up in communicable versus non-communicable diseases in an Iraqi refugee camp. Clinical Social Work and Health Intervention, 7(3), 38-41. doi:10.22359/cswhi_7_3_10

7. KOLlarova A, HUCIK J, BOZIK J (2011). Social integration of young adults from fosters homes. In: Clinical Social Work Jornal / Michal Oláh, Peter G. Fedor -Freybergh. - Vienna: by international Scientific Group of Applied Preventive Medicine, 2011. - ISSN 2076-9741. - Roč. 2, č. 3 (2011) s. 60-67.

8. BARTOSOVIC I (2016) Some aspects of the health status of homeless people. Clinical Social Work and Health Intervention 7(1), 39-47. doi:10.22359/cswhi_7_1_04 
9. ARCH S, LEAKE B, KNOWLES L, GELBERG L (1998) Tuberculosis in homeless patients: potential for case finding in public emergency departments. Ann Emergency Med.; 32:144-7.
10. HWANG SW, BURNS T (2014). Health interventions for people who are homeless. The Lancet, 384(9953), 1541-1547. doi:10.1016/s0140-6736(14)61133-8 